\title{
MANAGEMENT OF THRIPS INFESTING MUNG BEAN USING PESTICIDES
}

\author{
S. Yasmin", M.A. Latif, M. Ali and M.M. Rahman \\ Department of Entomology, Sher-e-Bangla Agricultural University \\ Sher-e-Bangla Nagar, Dhaka-1207, Bangladesh
}

\begin{abstract}
The study was conducted to evaluate the effect of bio-pesticides and chemical insecticides namely Novastar 56EC, Stargate 48SC, Confidor 70WG, Actara 25aWG, Tracer 45SC, Ecomec 1.8EC, Bioneem plus 1EC to control thrips infesting mung bean in the experimental field of Sher-eBangla Agricultural University during November 2017 to February 2018. An untreated control observation was also evaluated. Efficacy of the treatments differed significantly and showed effective results in reduction of thrips population and infestation on mung bean at vegetative and reproductive growth stages of the plant. Stargate 48SC (clothianidin) was the most effective insecticide against the thrips species Megalurothrips usitatus and Thrips palmi with the highest reduction of population on top trifoliate leaves and terminal shoots ( 100.00 and $89.40 \%$, respectively) at vegetative stage and reduction on flower buds and flowers (86.04 and $85.95 \%$, respectively) at reproductive stage of mung bean. The lowest flower bud and flower infestation (7.22 and $3.41 \%$, respectively) and shedding (4.21 and $1.06 \%$, respectively) by thrips with the highest number of pod $\left(23.80\right.$ plant $\left.^{-1}\right)$, seed $\left(10.20\right.$ pod $\left.^{-1}\right)$, 1000 seed weight $(48.40 \mathrm{~g})$ and yield $\left(1026.91 \mathrm{~kg} \mathrm{ha}^{-1}\right)$ were also found in Stargate 48SC treated plots followed by Confidor 70WG and Actara 25WG treatments.
\end{abstract}

Keywords: Bio-pesticides, Chemical insecticides, Mung bean, Megalurothrips usitatus, Thrips palmi.

\section{INTRODUCTION}

Mung bean (Vigna radiata L.), is one of the most important pulse crops in Bangladesh, ranks $4^{\text {th }}$ in terms of acreage and production. Mung bean production in Bangladesh is about 32 thousand metric tons in the area of 96 thousand acres and the average yield is $341 \mathrm{~kg} \mathrm{acre-}{ }^{1}$ (BBS, 2015). Mung bean contains about $51 \%$ carbohydrate, $26 \%$ protein, $4 \%$ mineral, $3 \%$ vitamins (Yadav et al., 1994). Mung

\footnotetext{
*Corresponding author: saberasau@gmail.com
} 
bean is suitable for summer season but it can be grown in Kharif-I, Kharif-II and Late Rabi season in different regions of Bangladesh. Among several biotic and abiotic stresses, attack of insect pests is one of the major limiting factors of mung bean production. Insect pests are responsible for $42 \%$ and 58\% losses at pre-flowering and post-flowering stages, respectively of mung bean (Malik, 1992). Thrips is one of the major insect pests causing considerable losses of mung bean. Severe attacks of Megalurothrips usitatus cause yield losses of mung bean from $13 \%$ to $64 \%$ (Farajallah, 2013). During vegetative stage, M. usitatus feed inside vegetative buds, rasp the top, unopened trifoliate leaves and suck plant juice oozing out of the plant part. In the initial blooming stage, male and female thrips randomly distributed within the flowers. Both larvae and adults feed on pollen and rasp other flower parts and suck the plant juice oozing out from the injured plant parts. As a result of this type of damage, flowers drop of and affects on pod formation. Losses caused by petal and fruit malformation and scarring are of even greater economic importance (Zhang et al., 2007). Thrips occur every growing season and cause yield losses through premature dropping of flowers. Thrips can cause various levels of damage to the bean pod, from light scaring to severely twisted and scared pods. Thrips palmi attacks various legumes, fruiting and leafy vegetables in many countries in tropical and subtropical regions cause economic damage to plant crops both as a direct result of its feeding activity and from its ability to vector tospoviruses such as Watermelon Bud Necrosis Virus (WBNV) and Peanut Yellow Spot Virus (PYSV) (Gopal et al., 2010). Thrips populations are higher during the dry season, which favors rapid multiplication of thrips. So, it is necessary to control thrips in a safer and effective way for getting higher yield of mungbean. Farmers usually like to get results quickly but environmental safety is also an important considering factor. Neem based pesticides are reported to control young nymphs, inhibit growth and development of older nymphs and reduce egg-laying by adult thrips. Adding 0.1 to $0.5 \%$ of soft soap enhances efficacy of neem-based pesticides. Sucking pests have developed resistance to almost all conventional synthetic insecticides and also developing resistance to multiple classes of insecticides (Palumbo et al., 2001). Moreover, conventional insecticides provide poor control of insect pests and generally lead to pest resurgence. Therefore, to overcome these problems the use of bio-pesticides and new generation chemical neonicotinoids with novel mode of action that are active at very low dosages and manage thrips population, is the ultimate alternative for effective pest management. Hence, the present study was planned to investigate the relative toxicity of some bio-pesticides and newer chemical insecticides in order to find an effective control of thrips infesting mung bean.

\section{MATERIALS AND METHODS}

The experiment was conducted in the field of Sher-e-Bangla Agricultural University (SAU), Sher-e-Bangla Nagar, Dhaka, Bangladesh during November 2017 to February 2018. The plots were well prepared with good tilth and recommended 
fertilizers were applied for mung bean production during final land preparation (BARC, 2012). The experiments were laid out in Randomized Completely Block Design with three replications. The treatments were randomly allotted in each block. The seeds of BARI Mung- 6 were directly sown on 2 November, 2017 in $2.5 \mathrm{~m} \times 2 \mathrm{~m}$ experimental unit plot with a distance of $50 \mathrm{~cm}$ between the plots and $100 \mathrm{~cm}$ between the replications on 2 November, 2017. The seeds were sown in rows with the spacing of $30 \mathrm{~cm}$. The population of the plant was maintained constant by keeping plant to plant distance of $10 \mathrm{~cm}$. After sowing seeds, irrigation and other intercultural operations were done. Eight treatments including Novastar 56EC @ 1 ml, Stargate 48SC @ 0.4 ml, Confidor 70WG @ 0.2 g, Actara 25WG @0.2 g, Tracer 45SC@ $0.4 \mathrm{ml}$, Ecomec 1.8EC @ $1 \mathrm{ml}$, Bioneem plus 1EC @ 1 $\mathrm{ml} \mathrm{L}^{-1}$ of water and untreated control were tested. Chemical insecticides and bio-pesticides were applied at 7 days interval to the foliage at vegetative stage when the thrips appeared and continued till reproductive stage of the crop. Ten mung bean plants were randomly selected from each plot avoiding border plants. A white paper was placed under the top trifoliate leaves of the each selected plant and shaked rapidly by using a soft brush (beating method). Then the number of adult Megalurothrips usitatus and Thrips palmi was counted. Data were collected two times at weekly intervals from top trifoliate leaves at vegetative stage. After counting thrips population, treatments were applied and data were collected after 7 days following the same procedures. Similarly, the number of adult M. usitatus and T. palmi was counted two times from terminal shoots from the selected plants at vegetative stage. As such the number of thrips of the two species was counted from ten flower buds and ten flowers of those selected plants of each plot at reproductive stage. Data were collected ten times at weekly interval and treatments were applied after counting of adult thrips at every inspection. Percent reduction of thrips over untreated control was calculated. Number of total flower buds and flowers, number of infested flower buds and flowers, shedding flower buds and flowers plant ${ }^{-1}$ were recorded from the ten selected plants of each plot. Percent infestation and percent shedding of flower buds and flowers were also calculated. Harvesting was done three times when pods were matured. All pods were separated and counted from ten sample plants and the average number of pod plant ${ }^{-1}$ was calculated at each harvest. The average pod length and number of seed pod $^{-1}$ were recorded after harvesting from ten randomly selected pods and 1000 seed weight was taken from each plot at every harvest. Seed yield data was converted into $\mathrm{kg} \mathrm{ha}^{-1}$ for each plot.

Statistical analysis: Data were analyzed by using MSTAT software. The significant differences among the treatment means were compared by DMRT at 5\% level of probability. 


\section{RESULTS}

Significant variations in efficacy of different bio-pesticides and chemical insecticides were observed at vegetative stage of mung bean in comparison to control. Stargate 48SC treatment (clothianidin) was found very effective to control thrips and there was no thrips on top trifoliate leaves in this treatment. The lowest number of $M$. usitatus and T. palmi (0.99 and 0.02, respectively) on 10 terminal $\operatorname{shoot}^{-1}$ was found in Stargate 48SC treated plot. On the other hand, the highest incidence of $M$. usitatus and T. palmi (5.76 and 2.25, respectively) on10 top trifoliate leaves ${ }^{-1}$ and that of $M$. usitatus and $T$. palmi (6.77 and 2.78, respectively) on 10 terminal shoots $^{-1}$ was recorded in untreated control plot. Stargate 48SC reduced maximum thrips population $100.00 \%$ on top trifoliate leaves and $89.40 \%$ on terminal shoots followed by Confidor 70 WG $(81.25 \%$ on top trifoliate leaves and $82.61 \%$ on terminal shoots). Among the Bio-pesticides, Ecomec 1.8EC performed better in reducing thrips population $(43.60 \%$ and $46.65 \%)$ on top trifoliate leaves and terminal shoots, respectively (Table 1$)$.

Table 1. Efficacy of the pesticides on the abundance of thrips on top trifoliate leaves and terminal shoots of mung bean at vegetative stage of the crop

\begin{tabular}{|c|c|c|c|c|c|c|c|c|}
\hline \multirow[t]{2}{*}{ Treatment } & \multicolumn{3}{|c|}{$\begin{array}{c}\text { Mean No. of thrips } \\
10 \text { top trifoliate leaves }\end{array}$} & \multirow{2}{*}{$\begin{array}{c}\% \\
\text { reduction } \\
\text { of thrips } \\
\text { over } \\
\text { control }\end{array}$} & \multicolumn{3}{|c|}{$\begin{array}{l}\text { Mean No. of thrips } \\
10 \text { terminal shoots }^{-1}\end{array}$} & \multirow{2}{*}{$\begin{array}{c}\% \\
\text { reduction } \\
\text { of thrips } \\
\text { over } \\
\text { control }\end{array}$} \\
\hline & $\begin{array}{c}\text { M. } \\
\text { usitatus }\end{array}$ & $\begin{array}{c}T . \\
\text { palmi }\end{array}$ & $\begin{array}{l}\text { Cumulativ } \\
\text { e mean } \\
\text { No. of } \\
\text { two thrips } \\
\text { species }\end{array}$ & & $\begin{array}{c}M . \\
\text { usitatus }\end{array}$ & T. palmi & $\begin{array}{c}\text { Cumulat } \\
\text { ive mean } \\
\text { No. of } \\
\text { two } \\
\text { thrips } \\
\text { species }\end{array}$ & \\
\hline Novastar 56 EC & $2.76 \mathrm{~d}$ & $0.99 \mathrm{~d}$ & $3.75 \mathrm{e}$ & $52.92 \mathrm{~d}$ & $3.18 \mathrm{c}$ & $1.10 \mathrm{~d}$ & $4.28 \mathrm{e}$ & $54.87 \mathrm{c}$ \\
\hline Stargate 48 SC & $0.00 \mathrm{f}$ & $0.00 \mathrm{~g}$ & $0.00 \mathrm{~h}$ & $100.00 \mathrm{a}$ & $0.99 \mathrm{~d}$ & $0.02 \mathrm{f}$ & $1.01 \mathrm{~g}$ & $89.40 \mathrm{a}$ \\
\hline Confidor $70 \mathrm{WG}$ & $1.25 \mathrm{e}$ & $0.25 \mathrm{f}$ & $1.50 \mathrm{~g}$ & $81.25 \mathrm{~b}$ & $1.26 \mathrm{~d}$ & $0.39 \mathrm{e}$ & $1.65 \mathrm{~g}$ & $82.61 \mathrm{a}$ \\
\hline Actara $25 \mathrm{WG}$ & $1.50 \mathrm{e}$ & $0.74 \mathrm{e}$ & $2.24 \mathrm{f}$ & $71.94 \mathrm{c}$ & $1.74 \mathrm{~d}$ & $1.00 \mathrm{~d}$ & $2.74 \mathrm{f}$ & $71.23 \mathrm{~b}$ \\
\hline Tracer 45 SC & $4.73 \mathrm{c}$ & $1.51 \mathrm{~b}$ & $6.24 \mathrm{c}$ & $21.95 \mathrm{f}$ & $4.83 \mathrm{~b}$ & $1.42 \mathrm{c}$ & $6.25 \mathrm{c}$ & $33.94 \mathrm{e}$ \\
\hline Ecomec $1.8 \mathrm{EC}$ & $3.24 \mathrm{~d}$ & $1.25 \mathrm{c}$ & $4.49 \mathrm{~d}$ & $43.60 \mathrm{e}$ & $3.85 \mathrm{c}$ & $1.23 \mathrm{~cd}$ & $5.08 \mathrm{~d}$ & $46.65 \mathrm{~d}$ \\
\hline Bioneem plus 1EC & $5.26 \mathrm{~b}$ & $1.49 \mathrm{~b}$ & $6.75 \mathrm{~b}$ & $15.35 \mathrm{~g}$ & $5.25 \mathrm{~b}$ & $2.14 \mathrm{~b}$ & $7.39 \mathrm{~b}$ & $21.90 \mathrm{f}$ \\
\hline Untreated control & $5.76 \mathrm{a}$ & $2.25 \mathrm{a}$ & $8.01 \mathrm{a}$ & - & $6.77 \mathrm{a}$ & $2.78 \mathrm{a}$ & $9.55 \mathrm{a}$ & - \\
\hline $\operatorname{LSD}_{(0.05)}$ & 0.49 & 0.16 & 6.88 & 6.43 & 0.82 & 0.24 & 0.72 & 8.09 \\
\hline $\mathrm{CV}(\%)$ & 9.45 & 9.19 & 0.48 & 6.53 & 13.84 & 11.24 & 8.97 & 7.95 \\
\hline
\end{tabular}

In a column means having similar letter(s) are statistically identical at $5 \%$ level by DMRT.

The data on mean number of thrips (M. usitatus and T. palmi) per 10 flower buds and 10 flowers of mung bean presented in Table 2 revealed that significantly the lowest number of adult M. usitatus (1.66) on 10 flower bud ${ }^{-1}$ and (1.87) on 10 flower $^{-1}$ was 
recorded in Stargate 48SC treated plot. There was no T. palmi on flower bud and the lowest number (0.11) on10 flower ${ }^{-1}$ was found in Stargate 48SC treated plot. On the other hand, the highest population of M. usitatus and T. palmi (8.98 and 3.08, respectively) on 10 flower bud ${ }^{-1}$ and that of M. usitatus and T. palmi (9.23 and 4.90, respectively) on 10 flower $^{-1}$ was recorded in untreated control plot. Stargate 48SC reduced the population $(86.04 \%$ on flower buds and $85.95 \%$ on flowers) followed by Confidor $70 W G$ ( $61.89 \%$ on flower buds and $62.56 \%$ on flowers). Among the Biopesticides, Ecomec 1.8EC performed better in reducing thrips population on flower buds and flowers (38.50\% and $37.13 \%$, respectively).

Table 2. Mean population of M. usitatus and T. palmi under different treatments on flower buds and flowers at flowering stage of mung bean

\begin{tabular}{|c|c|c|c|c|c|c|c|c|}
\hline \multirow[t]{2}{*}{ Treatment } & \multicolumn{3}{|c|}{$\begin{array}{l}\text { Mean No. of thrips } \\
10 \text { flower buds }^{-1}\end{array}$} & \multirow{2}{*}{$\begin{array}{c}\% \\
\text { reduction } \\
\text { of thrips } \\
\text { over } \\
\text { control }\end{array}$} & \multicolumn{3}{|c|}{$\begin{array}{l}\text { Mean No. of thrips } \\
10 \text { flowers }^{-1}\end{array}$} & \multirow{2}{*}{$\begin{array}{c}\% \\
\text { reduction } \\
\text { of thrips } \\
\text { over } \\
\text { control }\end{array}$} \\
\hline & $\begin{array}{c}\text { M. } \\
\text { usitatus }\end{array}$ & T. palmi & $\begin{array}{c}\text { Cumulati } \\
\text { ve mean } \\
\text { No. of } \\
\text { two thrips } \\
\text { species }\end{array}$ & & $\begin{array}{c}M . \\
\text { usitatus }\end{array}$ & $\begin{array}{c}T . \\
\text { palmi }\end{array}$ & $\begin{array}{c}\text { Cumulati } \\
\text { ve mean } \\
\text { No. of } \\
\text { two thrips } \\
\text { species }\end{array}$ & \\
\hline Novastar 56 EC & $4.83 \mathrm{~cd}$ & $1.62 \mathrm{c}$ & $6.45 \mathrm{de}$ & $46.14 \mathrm{~cd}$ & $5.13 \mathrm{~d}$ & $2.10 \mathrm{c}$ & $7.23 \mathrm{~d}$ & $48.72 \mathrm{c}$ \\
\hline Stargate $48 \mathrm{SC}$ & $1.66 \mathrm{e}$ & $0.00 \mathrm{e}$ & $1.66 \mathrm{~g}$ & $86.04 \mathrm{a}$ & $1.87 \mathrm{e}$ & $0.11 \mathrm{f}$ & $1.98 \mathrm{f}$ & $85.95 \mathrm{a}$ \\
\hline Confidor $70 \mathrm{WG}$ & $4.25 \mathrm{~d}$ & $0.33 \mathrm{~d}$ & $4.58 \mathrm{f}$ & $61.89 \mathrm{~b}$ & $4.52 \mathrm{~d}$ & $0.75 \mathrm{e}$ & $5.27 \mathrm{e}$ & $62.56 \mathrm{~b}$ \\
\hline Actara $25 \mathrm{WG}$ & $4.38 \mathrm{~d}$ & $1.54 \mathrm{c}$ & $5.92 \mathrm{e}$ & $50.70 \mathrm{bc}$ & $5.03 \mathrm{~d}$ & $1.43 \mathrm{~d}$ & $6.46 \mathrm{~d}$ & $54.01 \mathrm{c}$ \\
\hline Tracer 45 SC & $6.11 \mathrm{~b}$ & $1.97 \mathrm{~b}$ & $8.08 \mathrm{c}$ & $32.01 \mathrm{ef}$ & $6.87 \mathrm{c}$ & $2.38 \mathrm{c}$ & $9.25 \mathrm{c}$ & $34.45 \mathrm{~d}$ \\
\hline Ecomec $1.8 \mathrm{EC}$ & $5.73 \mathrm{bc}$ & $1.66 \mathrm{bc}$ & $7.39 \mathrm{~cd}$ & $38.50 \mathrm{de}$ & $6.62 c$ & $2.25 \mathrm{c}$ & $8.87 \mathrm{c}$ & $37.13 \mathrm{~d}$ \\
\hline Bioneem plus 1EC & $6.63 \mathrm{~b}$ & $2.83 \mathrm{a}$ & $9.46 \mathrm{~b}$ & $20.70 \mathrm{f}$ & $7.89 \mathrm{~b}$ & $3.97 \mathrm{~b}$ & $11.86 b$ & $15.77 \mathrm{e}$ \\
\hline Untreated control & $8.98 \mathrm{a}$ & $3.08 \mathrm{a}$ & $12.06 \mathrm{a}$ & - & $9.23 \mathrm{a}$ & $4.90 \mathrm{a}$ & $14.13 \mathrm{a}$ & - \\
\hline $\operatorname{LSD}_{(0.05)}$ & 1.04 & 0.33 & 1.31 & 11.66 & 1.00 & 0.38 & 0.94 & 6.69 \\
\hline $\mathrm{CV}(\%)$ & 11.53 & 11.91 & 11.14 & 13.66 & 10.00 & 10.10 & 6.85 & 7.77 \\
\hline
\end{tabular}

In a column means having similar letter(s) are statistically identical at 5\% level by DMRT.

Flower bud infestation and shedding by thrips were significantly affected by the application of bio-pesticides and chemical insecticides (Table 3). Among the treatments, the lowest infestation and shedding of flower bud $(7.22 \%$ and $4.21 \%$, respectively) by thrips was found in Stargate 48SC treated plot. This was statistically identical with Confidor 70WG and Actara 25 WG treatments. On the other hand, the highest infestation and shedding (14.29\% and $9.38 \%$, respectively) by thrips was recorded in control plot. 
Table 3. Effect of bio-pesticides and chemical insecticides on infestation and shedding of flower bud and flower of mung bean by thrips

\begin{tabular}{l|c|c|c|c}
\hline Treatment & $\begin{array}{c}\text { \% infestation } \\
\text { of flower bud } \\
\text { by thrips }\end{array}$ & $\begin{array}{c}\% \text { flower } \\
\text { bud } \\
\text { shedding }\end{array}$ & $\begin{array}{c}\% \\
\text { infestation } \\
\text { of flower by } \\
\text { thrips }\end{array}$ & $\begin{array}{c}\text { \% flower } \\
\text { shedding by } \\
\text { thrips }\end{array}$ \\
\hline Novastar 56 EC & $9.94 \mathrm{~cd}$ & $6.01 \mathrm{c}$ & $21.03 \mathrm{e}$ & $11.06 \mathrm{e}$ \\
Stargate 48 SC & $7.22 \mathrm{e}$ & $4.21 \mathrm{~d}$ & $3.41 \mathrm{~g}$ & $1.06 \mathrm{~g}$ \\
Confidor 70 WG & $8.20 \mathrm{de}$ & $4.96 \mathrm{~cd}$ & $12.07 \mathrm{f}$ & $6.08 \mathrm{f}$ \\
Actara 25 WG & $9.17 \mathrm{cde}$ & $5.28 \mathrm{~cd}$ & $18.20 \mathrm{e}$ & $9.02 \mathrm{e}$ \\
Tracer 45 SC & $12.39 \mathrm{ab}$ & $8.08 \mathrm{ab}$ & $33.65 \mathrm{c}$ & $19.12 \mathrm{c}$ \\
Ecomec 1.8 EC & $10.85 \mathrm{bc}$ & $6.66 \mathrm{bc}$ & $26.59 \mathrm{~d}$ & $15.49 \mathrm{~d}$ \\
Bioneem plus 1EC & $13.38 \mathrm{a}$ & $8.50 \mathrm{a}$ & $41.63 \mathrm{~b}$ & $25.53 \mathrm{~b}$ \\
Untreated control & $14.29 \mathrm{a}$ & $9.38 \mathrm{a}$ & $47.22 \mathrm{a}$ & $28.69 \mathrm{a}$ \\
\hline $\mathrm{LSD}_{(0.05)}$ & 1.92 & 1.58 & 4.79 & 2.33 \\
\hline $\mathrm{CV}$ & 10.62 & 14.05 & 11.14 & 9.50 \\
\hline
\end{tabular}

In a column means having similar letter(s) are statistically identical at 5\% level by DMRT.

Different bio-pesticides and chemical insecticides significantly affected the mung bean flower infestation and shedding by thrips (Table 3). Among the treatments, the lowest infestation and shedding of flower $(3.41 \%$ and $1.06 \%$, respectively) was observed in Stargate 48SC treated plots. On the other hand, the highest infestation and shedding of flower ( $47.22 \%$ and $28.69 \%$, respectively) was recorded in untreated control plot.

There was a positive relationship between number of thrips on flower and rate of flower shedding (Figure 1). The result showed that the flower shedding percentage increase with the increase of thrips population but pesticide's reduce the thrips population and flower shedding.

The data on number of pod plant ${ }^{-1}$, pod length, number of seed $\operatorname{pod}^{-1}, 1000$ seed weight and yield of mung bean under different treatments have been shown in Table 4. The highest number of pod $\left(23.80\right.$ plant $\left.^{-1}\right)$, pod length $(8.03 \mathrm{~cm})$, seed number $\left(10.20\right.$ pod $\left.^{-1}\right), 1000$ seed weight $(48.40 \mathrm{~g})$ and yield $\left(1026.91 \mathrm{~kg} \mathrm{ha}^{-1}\right)$ were observed in Stargate 48SC treated plot. This was statistically identical with Confidor 70WG and Actara $25 \mathrm{WG}$ treatments. The lowest number of pod $\left(16.40\right.$ plant $\left.^{-1}\right)$, pod length $(5.84 \mathrm{~cm})$, seed number $\left(6.97\right.$ pod $\left.^{-1}\right), 1000$ seed weight $(37.30 \mathrm{~g})$ and yield $(532.24 \mathrm{~kg}$ $\left.\mathrm{ha}^{-1}\right)$ were found in control plot. 


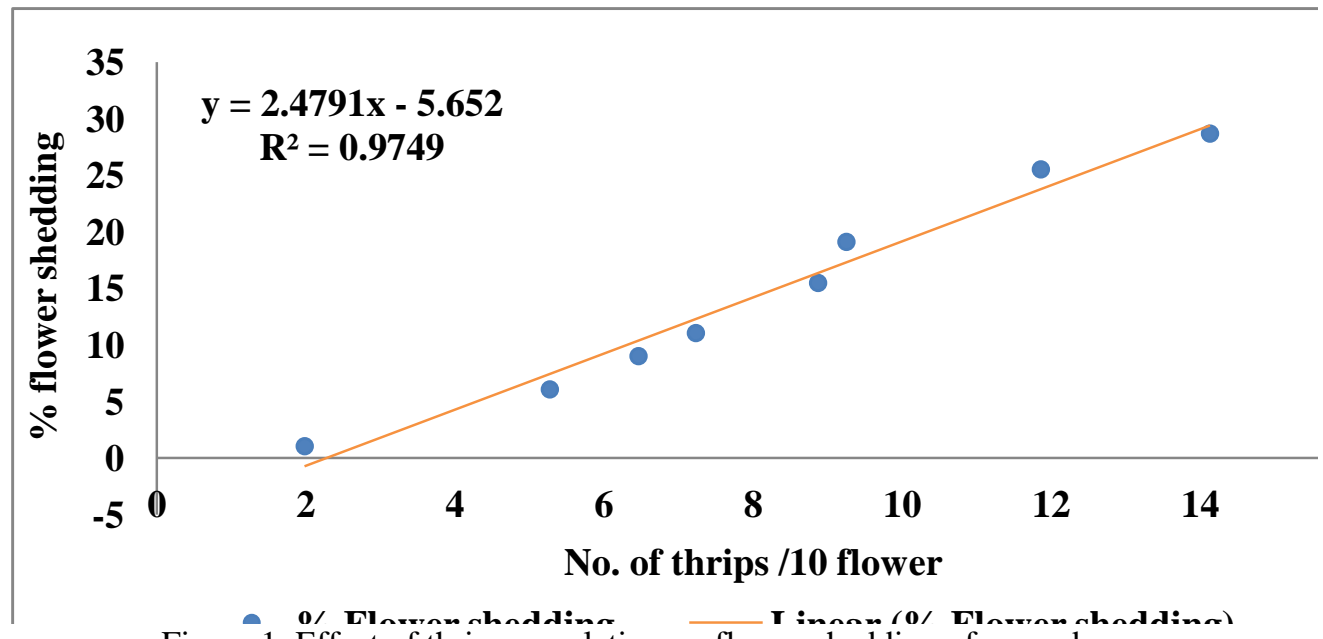

Figure 1. Effect of thrips population on flower shedding of mung bean.

Table 4. Effect of bio-pesticides and chemical insecticides on yield and yield contributing characters of mung bean

\begin{tabular}{l|c|c|c|c|c}
\hline Treatment & $\begin{array}{c}\text { Pod No. } \\
\text { plant }^{-1}\end{array}$ & $\begin{array}{c}\text { Pod } \\
\text { length } \\
(\mathrm{cm})\end{array}$ & $\begin{array}{c}\text { Seed No. } \\
\text { pod }^{-1}\end{array}$ & $\begin{array}{c}1000 \mathrm{seed} \\
\text { weight }(\mathrm{g})\end{array}$ & $\begin{array}{c}\text { Yield } \\
\left(\mathrm{kg} \mathrm{ha}^{-1}\right)\end{array}$ \\
\hline Novastar 56 EC & $20.70 \mathrm{abc}$ & $7.22 \mathrm{ab}$ & $8.70 \mathrm{bcd}$ & $45.20 \mathrm{~b}$ & $871.43 \mathrm{~b}$ \\
Stargate 48 SC & $23.80 \mathrm{a}$ & $8.03 \mathrm{a}$ & $10.20 \mathrm{a}$ & $48.40 \mathrm{a}$ & $1026.91 \mathrm{a}$ \\
Confidor 70 WG & $22.40 \mathrm{ab}$ & $7.82 \mathrm{a}$ & $9.30 \mathrm{ab}$ & $47.10 \mathrm{ab}$ & $991.26 \mathrm{a}$ \\
Actara 25 WG & $21.20 \mathrm{abc}$ & $7.36 \mathrm{ab}$ & $9.00 \mathrm{bc}$ & $46.40 \mathrm{ab}$ & $970.22 \mathrm{a}$ \\
Tracer 45 SC & $18.80 \mathrm{~cd}$ & $6.84 \mathrm{abc}$ & $8.10 \mathrm{~cd}$ & $44.10 \mathrm{~b}$ & $774.12 \mathrm{bc}$ \\
Ecomec 1.8 EC & $19.70 \mathrm{bcd}$ & $7.13 \mathrm{ab}$ & $8.50 \mathrm{bcd}$ & $44.70 \mathrm{~b}$ & $792.80 \mathrm{~b}$ \\
Bioneem plus 1EC & $17.20 \mathrm{~d}$ & $6.34 \mathrm{bc}$ & $7.80 \mathrm{de}$ & $40.70 \mathrm{c}$ & $691.37 \mathrm{c}$ \\
Untreated control & $16.40 \mathrm{~d}$ & $5.84 \mathrm{c}$ & $6.97 \mathrm{e}$ & $37.30 \mathrm{~d}$ & $532.24 \mathrm{~d}$ \\
\hline $\mathrm{LSD}_{(0.05)}$ & 3.13 & 1.11 & 1.06 & 2.94 & 94.72 \\
\hline $\mathrm{CV}_{(\%)}$ & 9.26 & 9.28 & 7.34 & 3.94 & 6.75 \\
\hline
\end{tabular}

In a column means having similar letter(s) are statistically identical at 5\% level by DMRT.

\section{DISCUSSION}

The present study revealed that two thrips species including $M$. usitatus and T. palmi was observed on vegetative plant parts i.e. young top leaves and terminal shoots of mung bean before flowering. In Stargate 48SC treated plots, no thrips population was found on top trifoliate leaves but in other treatments thrips population was observed. The lowest number of M. usitatus and T. palmi was recorded on terminal shoot of 
mung bean in Stargate 48SC treated plots. As thrips likes to habitat in hinder or closer parts of the plant, the number of thrips population was higher in terminal shoots than top trifoliate leaves at vegetative stage. After initiation of inflorescence, thrips population started to migrate on flower buds and flowers as they prefer floral parts for pollen and nectar. The lowest number of thrips on flower buds (1.66) and flowers (1.98) was found in Stargate 48SC treated plots followed by Confidor 70WG and Actara 25WG treated plots. Stargate 48SC (clothianidin) is a neonicotinoid insecticide act as nicotinic acetylcholine receptor agonists, reduces the maximum thrips population on different plant parts of mung bean. Then the effective treatment was Confidor 70WG (imidacloprid) followed by Actara 25WG (thiamethoxam) in controlling thrips population. Among the bio-pesticides, Ecomec 1.8EC (abamectin) which is neuroactive and affects ion transfer through cell membrane, showed better performance in controlling M. usitatus and T. palmi population on different plant parts both at vegetative and reproductive stage of mung bean than other biopesticieds i.e., Tracer 45 SC (spinosad) and Bioneem plus 1EC. The highest number of thrips population was observed in untreated control plots during the cropping period. Kasina et al. (2009) reported that during development of french bean crop, the thrips can only forage on vegetative plant parts as the crop has not flowered. The high thrips number on flowers, could be due to upward migration of thrips from lower canopy in addition to new infestations from nearby other host plants (Reitz, 2002). Seal (2011) reported that various insecticides of the neonicotinoid group provided $42 \%$ to $75 \%$ control of $T$. palmi and clothianidin provided higher level (>70\%) of T. palmi control. Patil et al. (2007) reported better performance of clothianidin and acetamiprid against thrips infesting Indian bean. Ahirwar et al. (2016) reported that the effect of thiamethoxam on thrips population (1.54) per 6 trifoliate mung bean leaves was more followed by imidacloprid (2.11). Abamectin provided over $60 \%$ reduction of $T$. palmi on bean. Kar et al. (2018) recorded the mean thrips population ranged from 6.2 to 23.2 numbers 10 flowers ${ }^{-1}$ of mung bean among the treatments as against 38.3 numbers 10 flowers $^{-1}$ in control. Jensen (1995) found that spinosad showed very little onion thrips control, although other tests had shown it to be active against other types of thrips, which also supports the present findings. Hossain (2015) reported that application of imidacloprid at different growth stages of mung bean suppressed thrips population and flower infestation significantly.

In the present investigation, the lowest percent infestation and shedding of flower bud and flower was observed in Stargate 48SC treated mung bean crop which produced higher pods (23.80 plant $\left.^{-1}\right)$, seeds $\left(10.20\right.$ pod $\left.^{-1}\right)$ and yield $\left(1026.91 \mathrm{~kg} \mathrm{ha}^{-1}\right)$ followed by Confidor $70 \mathrm{WG}$ and Actara $25 \mathrm{WG}$ treated plots. Among bio-pesticides, Ecomec 1.8EC showed comparatively, better result than Tracer 45SC and Bioneem plus 1EC that performed poorly against thrips resulting higher infestation and shedding of mung bean flower bud and flower. As thrips likes to feed on pollen and rasp other floral parts and suck the juices oozing out from the injured parts, causes flower bud 
and flower shedding, which effects on lower pod setting, malformation of pod and yield of mung bean. Tamo et al. (1993) reported that thrips is an important pest of the reproductive structures (flower buds and flowers) of cowpea, with early feeding leading to flower bud and flower dropping and consequently poor pod setting. Mumutaj (2014) reported that the lowest mungbean flower shedding $(6.02 \%)$ was found in Talstar 2WP followed by Confidor 70WG (6.99\%), Dursban 20EC (8.10\%) and Actara 25WG (10.08\%). Neem oil showed poor performance and found $30.02 \%$ flower shedding in mung bean field. Singh et al. (2016) reported that clothianidin 50 WDG produced maximum yield $6.67 \mathrm{q} \mathrm{ha}^{-1}$ while the control plot yielded $3.39 \mathrm{q} \mathrm{ha}^{-1}$.

\section{CONCLUSION}

Among the bio-pesticides and chemical insecticides, Stargate 48SC was the most effective to control thrips, as it showed lower infestation and shedding of flower bud and flower which cause higher pod formation and yield of mungbean. Among the bio-pesticides, Ecomec 1.8EC treated plots showed better result in controlling thrips. Stargate 48 SC would be the most effective treatment to suppress thrips population during that time as well as the remaining cropping period.

\section{ACKNOWLEDGEMENTS}

The authors thank the Ministry of Science and Technology (Bangladesh) authority for financial support to conduct the study.

\section{REFERENCES}

Ahirwar, B., Bhowmick, A.K., Gupta, P.K., Khan, M.A., Sharma, S.R. and Nayak, S. (2016). Efficacy of insecticides against sucking pests and yield of mung bean. Annals of Plant Protection Sciences, 24(1): 34-37.

BARC (Bangladesh Agricultural Research Council). (2012). Fertilizer recommendation for different crops. Fertilizer recommendation Guide-2012. p.102.

BBS (Bangladesh Bureau of Statistics). (2015). Yearbook of Agricultural Statistics of Bangladesh. Statistics Division, Ministry of Planning, Government of the People's Republic of Bangladesh, Dhaka. p.115.

Farajallah, A. (2013). Effect of chemical and botanical insecticides on thrips and yield of mungbean. Indonesian journal of agriculture, 6(2): 87-92.

Gopal, K., Krishnareddy, M., Reddy, D.V.R. and Muniyappa, V. (2010). Transmission of Peanut yellow spot virus (PYSV) by thrips, Scirtothrips dorsalis Hood. in groundnut. Archives of Phytopathology and Plant Protection, 43(5): 421-429.

Hossain, M.A. (2015). Efficacy of some insecticides against insect pests of mungbean (Vigna radiata L.). Bangladesh Journal of Agricultural Research, 40(4): 657-667.

Jensen, L. (1995). Strategies for controlling onion thrips (Thrips tabaci) in sweet Spanish .nions. Malheur County Extension Office, Oregon State University, Ontario. pp. 26-33. 
Kar, A., Sasmal, A., Mishra, I.O.P. and Panda, P.K. (2018). Relative efficacy and economics of seed treatment and newer insecticides against sucking and borer pests of summer mungbean in coastal Odisha. Journal of Entomology and Zoology Studies, 6(2): 22622268.

Kasina, M. (2009). Within-plant distribution and seasonal population dynamics of flower thrips (Thysanoptera: Thripidae) infesting French beans (Phaseolus vulgaris L.) in Kenya. Spanish Journal of Agricultural Research, 7(3): 652-659.

Malik, M.R. (1992). Economics of insecticides use in mung bean. Pakistan Journal of Agricultural Research, 13(3): 267-272.

Mumutaj, H. (2014). Management of mung bean thrips (Megalurothrips distalis) using chemical insecticides and neem oil. MS thesis, Sher-e-Bangla Agricultural Univ., Dhaka. 1-64.

Palumbo, J.C., Horowitz, A.R. and Prabhaker, N. (2001). Insecticidal control and resistance management for Bemisia tabaci. Crop Protection, 20: 739-765.

Patil, S.B., Udikeri, S.S., Naik, L.K., Rachappa, V., Nimbal, F. and Guruprasad, G.S. (2007). A promising new molecule for the management of cotton sap feeding insects. Karnataka Journal of Agricultural Sciences, 20(1): 47-50.

Reitz, S.R. (2002). Seasonal and within plant distribution of Frankliniella thrips (Thysanoptera: Thripidae) in North Florida tomatoes. Florida Entomologist, 85: 431439.

Seal, D.R. (2011). Abundance and Management of Melon Thrips, Thrips palmi Karny (Thysanoptera: Thripidae). Proceedings of Florida State Horticultural Society, 124:140-143.

Singh, P.S., Mishra, H and Singh, S.K. (2016). Evaluation of certain newer insecticides against the insect pests of mungbean, vigna radiata (L.) wilczek. Journal of Experimental Zoology India, 19(1): 367-372.

Tamo, B.J., Delucchi, V. and Harren, H.R. (1993). Assessment of key factors responsible for the pest status of the bean flower thrips, Megalurothrips sjostedti in West Africa. Bulletin of Entomological Research, 83(2): 251-258.

Yadav, D.S., Panwar, K.S. and Singh, V.K. (1994). Management of pulse crops in sequencial cropping. Proceedings of International Symposium on Pulse Research, April 2-6, 1994, New Delhi, India. 27p.

Zhang, Z.J., Wu, Q.J., Li, X.F., Zhang, Y.J., Xu, B.Y. and Zhu, G.R. (2007). Life history of western flower thrips, Frankliniella occidentalis (Thysanoptera: Thripidae), on five different vegetable leaves. Journal of Applied Entomology, 131: 347-354. 